Community: Volume 4, Nomor 1, April 2018

ISSN: 2477-5746

\title{
LESBIAN, GAY, BISEKSUAL, DAN TRANSGENDER (LGBT) DAN HAK ASASI MANUSIA (HAM)
}

\author{
Yeni Sri Lestari, S.IP., M.Soc.Sc \\ Sosiologi, Fakultas Ilmu Sosial dan Ilmu Politik, Universitas Teuku Umar \\ yenilestari24@yahoo.com
}

\begin{abstract}
The success of one country's democratic system is characterized by the increasing subsistence of freedoms owned by citizens such as freedom of expression, association to other individual freedoms as stated in the respective constitutions of a country. Notwithstanding the Universal Declaration of Human Rights (DUHAM), policies on human rights began to thrive in the world as the main pillar of democracy, one of which speaks of the recognition of LGBT rights. LGBT phenomena that hit most of the world are often viewed from two contradictory perspectives, those who legalize and which do not legalize (illegal). This study found that although both the United States and Indonesia share the principles of democracy in the life of the state, the Muslim majority of Indonesia views LGBT as a violation of Islamic values and norms, but the recognition of human rights is still appreciated only by the behavior of LGBT as an act of social aberrations.
\end{abstract}

Keyword: LGBT, HAM, Amerika dan Indonesia

\section{PENDAHULUAN}

Lesbian, Gay, Biseksual, dan Transgender (LGBT) merupakan pembahasan penting pada era sekarang melalui dominasi sistem demokrasi yang menjunjung tinggi kebebasan, khususnya kebebasan induvidu telah menciptakan ruang penting bagi keberadaan LGBT di kalangan masyarakat modern. Lahirnya LGBT sendiri didasari pada prinsip kebebasan dalam demokrasi yang mengakui adanya kebebasan untuk mengekspresikan diri.

LGBT sendiri identik dengan penyimpangan perilaku seksual, di mana orientasi seksual yang semestinya ialah hubungan yang melibatkan lawan jenis dan dengan satu pasangan, namun LGBT merupakan sebuah hubungan yang melibatkan sesama jenis, baik antara laki-laki dengan laki-laki, perempuan dengan perempuan, hingga orientasi seksual ganda di mana laki-laki berhubungan dengan perempuan serta laki-laki dan sebaliknya perempuan berhubungan dengan laki-laki juga dengan perempuan. Hal ini mengakibatkan lahirnya dua persepsi yang saling bertolak belakang terhadap eksistensi LGBT, khususnya dalam kehidupan bermasyarakat.

Besarnya keinginan kaum LGBT untuk diakui dan mendapatkan hak yang sama seperti masyarakat pada umumnya telah menciptakan polemik tersendiri yang 
sebagian besar menguras segala pemikiran para pengambil kebijakan, terutama dalam persoalan yang mengatasnamakan Hak Asasi Manusia (HAM). Munculnya keinginan untuk diakui dan diberikan hak yang bukan tanpa dasar, namun dikarenakan pada pandangan bahwa mereka (kaum LGBT) bukanlah sebuah penyakit sosial atau penyakit masyrakat.

Satu sisi lain, persepsi masyarakat luas atas fenomena LGBT terpecah menjadi dua, yaitu mereka yang menerima keberadaan kaum LGBT dan mereka yang tidak menerima keadaan individu maupun perilaku kaum LGBT. Perbedaan persepsi ini muncul karena adanya sudut pandang yang berbeda dalam melihat fenomena LGBT, utamanya sebagian besar dipengaruhi oleh keberadaan HAM yang secara universal menjadi pedoman bagi eksistensi pengakuan hak-hak sipil warga negara.

Konsep HAM yang dianut oleh sebuah negara seringkali memberikan pengaruh yang besar dalam kehidupan bermasyarakat bahkan turut mempengaruhi pembentukan sebuah kebijakan dalam segala bidang. Salah satunya dapat dianalisa melalui kajian tentang kedudukan kaum LGBT di negara Amerika yang mayoritas masyarakatnya merupakan masyarakat liberal dan menjunjung tinggi prinsip demokrasi dan kedudukan kaum LGBT di Indonesia yang merupakan sebuah negara demorkasi dengan sistem kebudayaan yang beraneka ragam dan menjunjung tinggi nilai adat, budaya hingga agama.

\section{KAJIAN PUSTAKA}

Kajian mengenai perspektif HAM mengenai LGBT telah banyak dilakukan, khususnya yang membahas mengenai keberadaan dan status LGBT berdasarkan HAM seperti kajian yang dilakukan oleh Meilanny Budiarti Santoso dengan judul LGBT Dalam Perspektif Hak Asasi Manusia. Kajian ini membahas mengenai resolusi tentang pengakuan hak-hak LGBT merupakanresolusi yang dikeluarkan oleh Perserikatan Bangsa-bangsa (PBB) yang pertama dan secara spesifik mengangkat isu pelanggaran HAM berdasarkan orientasi seksual dan identitas gender.

Resolusi tentang pengakuan atas hak-hak LGBT ini dijadikan sebagai acuan tuntutan bagi kaum LGBT untuk menuntut hak-hak mereka dengan mengatasnamakan HAM. Namun demikian, di Indonesia sendiri penegakkan terhadap hak-hak kaum LGBT harus disesuaikan dnegan aturan hukum dan nilai-nilai Pancasila sebagai dasar negara dan landasan falsafah kehidupan berbangsa dan negara.

Kajian Meilanny menekankan bahwa pengakuan terhadap hak-hak kaum LGBT di Indonesia pada dasarnya tidak terlepas dari nilai yang terkandung dalam falsafah hidup masyrakat Indonesia yaitu Pancasila. Pancasila sendiri memuat nilai-nilai yang berkaitan erta dengan agama, adat, budaya dan keanekaragaman, sehingga hal inilah yang menyebabkan perbedaan amalan penegakkan HAM di Indonesia dengan negara lainnya. 
Community: Volume 4, Nomor 1, April 2018

ISSN: 2477-5746

Kajian selanjutnya, dilakukan oleh Masthuriyah Sa'dan yang berjudul Agama dan HAM Memandang LGBT menjelaskan mengenai fenomena fatwa haram yang dikeluarkan oleh Majelis Ulama Indonesia (MUI) terhadap kelompok yang memiliki orientasi seksual menyimpang yaitu LGBT dengan hukuman mati terhadap pelaku seksual menyimpang menimbulkan polemik bagi masyarakat Indonesia. Hal ini sangat mengguncang mereka yang memiliki identitas gender ketiga yaitu kaum LGBT.

Masthuriyah mengemukakan bahwa seharusnya keberadaan agama memberikan kemudahan bagi fenomena LGBT bukan mengubur hidup-hidup seseorang yang memiliki kelainan orientasi seksual seperti kaum LGBT. Hal ini didasarkan kepada peraturan hukum regional, nasional, dan internasional mengenai HAM yang secara tegas mengakui hak-hak kaum LGBT sebagai manusia, serta penggunaan pendekatan sosial humanities kontemporer mendukung kelompok LGBT sebagai kumpulan manusia yang memiliki harkat dan martabat untuk diperlakukan sebagaimana layaknya manusia yang harus dihormati.

Kajian mengenai perspektif HAM terhadap kaum LGBT di Indonesia berdasarkan kajian Meilanny dan Masthuriyah memiliki pandangan yang berbeda. Meilanny menekankan bahwa Pancasila sebagai landasan hidup masyarakat Indonesia harus dihargai, sehingga keberadaan kaum LGBT haruslah tidak mencederai nilai nilai yang terkandung dalam Pancasila. Sedangkan Masthuriyah menekankan bahwa kaum LGBT haruslah diperlakukan selayaknya manusia normal lainnya.

Berdasarkan hal tersebut, jelas bahwa di Indonesia sendiri pandangan mengenai status kaum LGBT terbagi dua, yaitu mereka yang mendukung keberadaan LGBT dan mereka yang menolak keberadaan LGBT, kedua-duanya ditekankan kepada pendekatan kemanusian yang menggunakan konsep HAM.

Kajian mengenai keberadaan LGBT di Indonesia mengenai perspektif HAM sudah banyak dilakukan, namun pendekatan LGBT berdasarkan konsep HAM yang berbeda diimplementasikan oleh tiap-tiap negara haruslah menjadi acuan sehingga dalam menganalisa keberadaan LGBT berdasarkan HAM tidak terkesan dogmatis. Untuk memberikan gambaran yang tegas antara keberadaan LGBT di Indonesia yang memiliki perspektif HAM yang berbeda dengan perspektif HAM negara lain khususnya negara maju, maka keberadaan IGBT di Amerika turut dibahas dalam kajian ini, sehingga akan didapatkan perbandingan yang jelas antara perbedaan keberadaan kaum LGBT di kedua-dua negara.

\section{METODE PENELITIAN}

Metode penelitian yang digunakan dalam kajian ini adalah metode penelitian kualitatif, yaitu metode penelitian yang berlandaskan kepada filsafat postpositivisme. Metode ini digunakan untuk meneliti pada kondisi objek yang alamiah dimana hasil penelitian lebih menekankan kepada makna dari pada generalisasi (Sugiyono, 2013:9). Oleh karena itu, dalam kajian ini kaum LGBT menjadi objek utama dalam pembahasan. 
Sumber data utama dalam penelitian ini menggunakan data sekunderseperti buku, artikel, jurnal maupun bahan bacaan lainnya yang berkaitan dengan objek kajian. Data dikumpulkan menggunakan teknik pengumpulan data studi kepustakaan dengan cara memilih bacan-bacaan dan aturan yang terkait dengan keberadaan LGBT di Indonesia dan Amerika. Hasil analisa data akan disajikan secara deskriptif dengan cara menguraikan dan menggambarkan mengenai hal-hal yang terkait dengan permasalahan yang dikaji yaitu mengenai LGBT dan HAM di Indonesia dan Amerika.

\section{PEMBAHASAN DAN HASIL PENELITIAN}

Pembahasan dan hasil penelitian dalam kajian ini akan dibagi ke dalam tiga kategori, yaitu pertama pembahasan mengenai LGBT, kedua pembahasan mengenai HAM, dan ketiga pembahasan mengenai keberadaan LGBT menurut HAM yang terdapat dalam peraturan di Indonesia dan Amerika. Pembagian pembahasan ditujukan untuk memberikan kemudahan bagi memahami maksud yang menjadi tujuan dari kajian ini.

\section{Lesbi, Gay, Biseksual, dan Transgender (LGBT): pembahasan konseptual}

Istilah LGBT sudah tidak asing lagi pada zaman modern ini. Jauh sebelum istilah LGBT populer digaungkan, homoseks telah lama terdengar bahkan sejak zaman Nabi Luth as. Penggunaan istilah LGBT dirasa lebih menghargai keberadaan mereka yang memiliki identitas gender "ketiga" ini dibandingkan dengan sebutan lain seperti homo, waria, banci, bencong, dll yang dianggap mengandung konotasi kasar dan tidak sopan.

\section{a. Lesbi}

Lesbian berasal dari kata Lesbos yang merupakan pulau di tengah lautan Egis pada zaman kuno yang dihuni oleh para wanita saja. Berdasarkan motologi Yunani Kuno, diyakini di pulau tersebut terjalin hubungan percintaan sejenis antara putri Shappo dan Athis yang disebut dengan istilah cinta lesbis atau lesbiism (Kartini Kartono, 1989: 249). Mitologi ini kemudian berkembang dan diyakini oleh sebagian besar bangsa Barat dan mereka tidak menolak akan mitologi tersebut melainkan menjadikan mitologi tersebut sebagai sejarah terbentuknya hubungan percintaan sesama jenis antara perempuan dengan perempuan.

Secara umum lesbian merupakan orientasi seksual seorang perempuan yang hanya mempunyai rasa ketertarikan dengan sesama perempuan saja. Rasa ketertarikan antara perempuan dengan perempuan ini meliputi baik secara fisik, seksual, emosional maupun spiritual (Triana Adhiati, 2007: 26). Orientasi seksual lesbi ini memunculkan berbagai macam istilah seperti yang terdapat dalam tabel berikut: 
Community: Volume 4, Nomor 1, April 2018

ISSN: 2477-5746

Tabel 4.1. Kategori Lesbian

\begin{tabular}{|c|c|c|c|}
\hline No. & Istilah & Perilaku & Ciri \\
\hline 1. & $\begin{array}{l}\text { Butch/ } \\
\text { Butcy }\end{array}$ & $\begin{array}{l}\text { Perempuan yang berperan sebagai laki-laki } \\
\text { Soft Butcy (kesan feminim baik cara } \\
\text { berpakaian atau potongan rambut) } \\
\text { Stone Butcy (lebih maskulin baik cara } \\
\text { berpakaian maupun potongan rambut) }\end{array}$ & $\begin{array}{l}\text { Menggunakan pakaian } \\
\text { laki-laki, berperilaku } \\
\text { sebagai laki-laki } \\
\text { (tomboy), dominan, aktif, } \\
\text { agresif, melindungi, dll. }\end{array}$ \\
\hline 2. & Femme & $\begin{array}{l}\text { Perempuan yang berperan sebagai } \\
\text { perempuan }\end{array}$ & $\begin{array}{l}\text { Berpenampilan feminim, } \\
\text { berias diri, tidak berbeda } \\
\text { jauh dengan perempuan } \\
\text { pada umumnya, } \\
\text { pasangan pasif, hanya } \\
\text { menerima/menunggu } \\
\text { saja. }\end{array}$ \\
\hline 3. & $\begin{array}{c}\text { Andro/ } \\
\text { Androgy } \\
\text { ne }\end{array}$ & $\begin{array}{l}\text { Perempuan yang berperan sebagai laki-laki } \\
\text { atau perempuan }\end{array}$ & $\begin{array}{lr}\text { Fleksibel; menyesuaikan } \\
\text { penampilan } r \text { dengan } \\
\text { peran yang dijalankan } \\
\text { pada saat tertentu } \\
\text { (kondisi butch atau femme) }\end{array}$ \\
\hline 4. & No Label & $\begin{array}{l}\text { Perempuan yang berperan bukan sebagai } \\
\text { laki-laki maupun perempuan }\end{array}$ & Tidak memiliki ciri khas \\
\hline
\end{tabular}

Sumber: hasil susunan penulis

Lesbi dapat disimpulkan sebagai sebuah perasaan yang menyukai sesama jenis yaitu perempuan dengan perempuan, di mana perasaan tersebut melibatkan fisik, seksual, emosi, spiritual, maupun ikatan penting lainnya yang sangat kuat antara keduanya. Kaum lesbi memainkan peran masing-masing sebagai pasangan, yaitu ada yang berperan sebagai perempuan dan ada yang berperan sebagai laki-laki dalam hubungan yang mereka bangun.

Perilaku lesbian muncul dengan berbagai macam asumsi yang mendasarinya, terlepas dari berbagai pertentangan yang menyakini bahwa hal tersebut terjadi secara alamiah ataupun secara sadar. Untuk melihat gambaran mengenai faktor penyebab munculnya perilaku lesbi, maka akan disajikan pembahasan dalam tabel berikut:

Tabel 4.2. Faktor Penyebab Lesbi

\begin{tabular}{|c|c|c|l|}
\hline No. & Teori & Faktor & \multicolumn{1}{|c|}{ Keterangan } \\
\hline 1. & $\begin{array}{c}\text { Teori } \\
\text { Biologi }\end{array}$ & genetik & kecenderungan/bakat yang dibawa dari lahir \\
\cline { 3 - 4 } & & hormonal & $\begin{array}{l}\text { ketidakseimbangan hormon androgen sebelum dan } \\
\text { saat dewasa }\end{array}$ \\
\hline 2. & Teori & Pola asuh & Munculnya hubungan yang tidak baik antara anak \\
\hline
\end{tabular}




\begin{tabular}{|c|c|c|}
\hline \multirow[t]{4}{*}{ Psikososial } & & dan keluarga \\
\hline & $\begin{array}{c}\text { Trauma } \\
\text { kehidupan }\end{array}$ & $\begin{array}{l}\text { Pengalaman hubungan heteroseksual yang tidak } \\
\text { berhasil ataupun ketidakmampuan individu } \\
\text { memikat lawan jenis }\end{array}$ \\
\hline & $\begin{array}{l}\text { Tanda- } \\
\text { tanda } \\
\text { psikologis }\end{array}$ & Cara berpakaian dan berperilaku sejak dini \\
\hline & $\begin{array}{l}\text { Pengalaman } \\
\text { seks yang } \\
\text { pertama }\end{array}$ & $\begin{array}{l}\text { Pengalaman yang kurang menyenangkan dari } \\
\text { hubungan yang pernah dilalui }\end{array}$ \\
\hline
\end{tabular}

Sumber: Hasil Susunan Penulis

Berbagai faktor yang menyebabkan munculnya naluri atau keinginan untuk menjadi lesbi pada dasarnya telah memunculkan pro dan kontra dikalangan masyarakat luas. Sebagian menyakini bahwa perilaku lesbi merupakan faktor genetik dan hormonal yang terkandung dalam diri masing-masing individu, sedangkan faktor penguat didukung dengan kondisi sosial terutama lingkungan yang membentuk perilaku lesbi semakin matang.

\section{b. Gay}

Kata gay berasal dari Bahasa Perancis Kuno Abad ke-12 yang memiliki arti penuh suka cita, ceria, cahaya hati dan periang, kemudian gay mengalami pergeseran makna menjadi mencari kesenangan melalui kegiatan seksual yang tidak biasa (Zusy Aryanti, 2016: 44). Gay adalah seorang homoseksual berjenis kelamin laki-laki yang memiliki pasangan erotis, cinta maupun afeksinya juga laki-laki

Tabel 4.3. Metode Hubungan Pasangan Gay

\begin{tabular}{|c|c|c|lll|}
\hline No. & Istilah & Definisi & \multicolumn{3}{|c|}{ Keterangan } \\
\hline 1. & $\begin{array}{c}\text { Oral } \\
\text { Erotisme }\end{array}$ & Mulut & $\begin{array}{l}\text { Memanipulasi alat kelamin pasangannya dengan } \\
\text { memasukkan penis ke dalam mulut }\end{array}$ & Bengan \\
\hline 2. & Fellatio & Bibir & $\begin{array}{l}\text { Memanipulasi alat kelamin pasangan } \\
\text { menggelitik penis menggunakan bibir }\end{array}$ & dengan \\
\hline 3. & Cunnilingus & Lidah & $\begin{array}{l}\text { Memanipulasi alat kelamin pasangan dengan } \\
\text { memainkan lidah }\end{array}$ \\
\hline 4. & $\begin{array}{c}\text { Intervemora } \\
\text { Coitus }\end{array}$ & $\begin{array}{c}\text { Sela } \\
\text { Paha }\end{array}$ & Memanipulasi penis pasangan di sela-sela paha \\
\hline
\end{tabular}

Sumber: hasil susunan penulis

Fenomena homoseksual atau gay dewasa ini sudah menjadi isu hangat dan hampir dijumpai pada sebagian besar negara-negara dunia. Hal ini tidak terlepas dari penyebaran perilaku gay yang terjadi akibat pergaulan maupun faktor psikologis 
Community: Volume 4, Nomor 1, April 2018

ISSN: 2477-5746

masing-masing individu, namun tidak dapat dipungkiri, kemajuan zaman dan teknologi mengantarkan kepopuleran perilaku gay yang pada akhirnya menjadikan gay sebagai sebuah gaya hidup yang wajar dikalangan masyarakat modern kini.

\section{c. Biseksual}

Biseksual berasal dari kata bi yang berarti dua dan sexual yang berarti persetubuhan antara laki-laki dengan wanita, sehingga biseksual dapat diartikan sebagai ketertarikan kepada dua jenis kelamin yaitu laki-laki maupun perempuan (ketertarikan ganda) (Masthuriyah Sa'dan, 2016: 18). Biseksual dapat dikatakan sebagai perilaku menyukai lawan jenis ataupun sejenisnya, sehingga di satu waktu menjalin hubungan dengan lawan jenis tetapi di lain waktu dapat menjalin hubungan dengan sesama jenis.

Lebih tegas dan jelas, Crooks \& Baur (2005) membagi perilaku biseksual dalam 4 kategori, yaitu:

Tabel 4.4. Kategori Biseksual

\begin{tabular}{|c|c|c|}
\hline No. & Kategori & Ciri-ciri \\
\hline 1. & $\begin{array}{c}\text { Real } \\
\text { Orientation }\end{array}$ & $\begin{array}{l}\text { a. Tertarik pada laki-laki dan wanita sejak awal kehidupan dan } \\
\text { berlanjut hingga dewasa } \\
\text { b. Terlibat aktif dengan lebih dari satu pasangan } \\
\text { c. Memiliki ketertarikan terhadap kedua jenis kelamin secara } \\
\text { berterusan }\end{array}$ \\
\hline 2. & $\begin{array}{c}\text { Transitory } \\
\text { Orientation }\end{array}$ & $\begin{array}{l}\text { a. Orientasi seksual tidak dominan } \\
\text { b. Bersifat temporer } \\
\text { c. Faktor lingkungan }\end{array}$ \\
\hline 3. & $\begin{array}{l}\text { Transitional } \\
\text { Orientation }\end{array}$ & $\begin{array}{l}\text { a. Ada fase yang harus dilewati karena terdapat perubahan } \\
\text { dalam perilaku seksual yang didahulukan. Contoh: } \\
\text { heteroseksual menjadi homoseksual ataupun sebaliknya } \\
\text { b. Bersifat permanen (apabila individu telah melewati fase } \\
\text { preferensi seksual seperti dijelaskan pada poin a, maka } \\
\text { identitas terkahir akan cenderung bertahan untuk waktu } \\
\text { jangka panjang sehingga dapat dikatakan bahwa individu } \\
\text { tersebut bukan lagi seorang biseksual) }\end{array}$ \\
\hline 4. & $\begin{array}{l}\text { Homosexual } \\
\text { Denial }\end{array}$ & $\begin{array}{l}\text { a. Penyangkalan atas stigma negatif yang beredar dikalangan } \\
\text { masyarakat terhadap perilaku yang mereka anut. }\end{array}$ \\
\hline
\end{tabular}

Sumber: Hasil Susunan Penulis

Perilaku biseksual dapat disimpulkan muncul dari berbagai macam faktor seperti yang terdapat dalam tabel di atas, selain terbentuk sejak awal kehidupan yaitu melalui gen atau hormon yang ada di dalam tubuh juga dapat dipengaruhi oleh faktor lingkungan. Pengaruh gen dan hormonal sendiri pada dasarnya masih banyak 
menimbulkan pertentangan di kalangan para ahli mengenai perilaku LGBT termasuk salah satunya adalah lesbian.

\section{d. Transgender/transseksual}

Transgender secara etimologi berasal dari dua suku kata, yaitu trans yang memiliki arti berpindah tangan/berpindah tanggungan/pemindahan dan gender yang memiliki arti jenis kelamin (Pius A. Partanto dan M. Dahlan Al Barry: 757). Sehingga transgender secara umum dapat diartikan sebagai perubahan jenis kelamin dari lakilaki menjadi wanita ataupun sebaliknya.Istilah transgender juga dikenal dengan istilah transesksual yang berasal dari Bahasa Inggris, berarti pergantian jenis kelamin. Pergantian jenis kelamin ini dilakukan dengan cara melakukan prosedur operasi pergantian kelamin yang didasarkan kepada keinginan individu bersangkutan karena menginginkan adanya perubahan anatomi tubuh mereka.

Tabel 4.5. Kategori Transgender/Transeksual

\begin{tabular}{|c|c|l|l|l|}
\hline No. & Istilah & \multicolumn{1}{|c|}{ Perilaku } & \multicolumn{1}{|c|}{ Ciri } \\
\hline 1. & Transgender & $\begin{array}{l}\text { Menggunakan pakaian lawan } \\
\text { jenis dan berperilaku seperti } \\
\text { lawan jenis }\end{array}$ & $\begin{array}{l}\text { Merasa identitas gendernya } \\
\text { tidak sesuai namun tidak } \\
\text { merubah jenis kelaminnya }\end{array}$ \\
\hline 2. & $\begin{array}{l}\text { Cross dresser } \\
\text { Transvestite }\end{array}$ & $\begin{array}{l}\text { Merasakan kepuasan dengan } \\
\text { menggunakan pakaian lawan } \\
\text { jenis }\end{array}$ & $\begin{array}{l}\text { Sekedar bentuk ekspresi } \\
\text { gender bukan identitas } \\
\text { gender }\end{array}$ \\
\hline 3. & Transexual & $\begin{array}{l}\text { Menggunakan pakaian lawan } \\
\text { jenis dan berperilaku seperti } \\
\text { lawan jenis }\end{array}$ & Merubah jenis kelamin \\
\hline
\end{tabular}

Sumber: Hasil Susunan Penulis

Transgender/transeksual memiliki ciri-ciri yang membedakannya dengan kaum homoseks lainnya, hal ini seperti yang diuraikan oleh Jeffrey S. Nevid (2005), yaitu:

Tabel 4.6. Ciri-ciri klinis Transgender/transeksual

\begin{tabular}{|c|l|}
\hline No. & \multicolumn{1}{|c|}{ Ciri-ciri } \\
\hline 1. & Identitas yang kuat terhadap gender lainnya \\
\hline 2. & $\begin{array}{l}\text { Terdapat ekspresi yang berulang dari hasrat untuk menjadi anggota dari } \\
\text { gender lainnya }\end{array}$ \\
\hline 3. & $\begin{array}{l}\text { Preferensi untuk menggunakan pakaian yang menjadi stereotipikal dari gender } \\
\text { lainnya }\end{array}$ \\
\hline 4. & $\begin{array}{l}\text { Terdapat fantasi yang terus menerus untuk menjadi anggota dari gender } \\
\text { lainnya }\end{array}$ \\
\hline 5. & $\begin{array}{l}\text { Hasrat untuk berpartisipasi dalam kegiatan dan permainan yang merupakan } \\
\text { stereotip dari gender lainnya }\end{array}$ \\
\hline
\end{tabular}


Community: Volume 4, Nomor 1, April 2018

ISSN: 2477-5746

\begin{tabular}{|c|l|}
\hline 6. & Preferensi yang kuat untuk memiliki teman bermain dari gender lainnya \\
\hline 7. & Perasaan tidak nyaman dan puas terhadap anatomi gendernya sendiri \\
\hline 8. & Tidak ada kondisi interseks \\
\hline 9. & Menimbulkan distres yang serius \\
\hline
\end{tabular}

Sumber: Hasil Susunan Penulis

\section{Sejarah LGBT}

LGBT atau pada zaman dahulu populer dengan sebutan homoseks telah ada sejak zaman Nabi Luth As yang tertera dalam Al-Qur'an Surah Al-A'raf ayat 80-84. Negeri tempat tinggal Nabi Luth adalah Negeri Sadum, di mana masyarakat negeri tersebut telah mengalami kehancuran moral yaitu lebih menyukai sesama jenis (lakilaki dengan laki-laki), sedangkan kaum perempuan tidak diperdulikan.

Keberadaan kaum LGBT tidak dapat dipungkiri eksistensinya, meskipun secara tegas agama seperti Islam, Yahudi dan Kristen secara tegas dalam setiap kitabnya mengutuk perbuatan homoseksual, namun keberadaan mereka masih tetap ada namun secara sembunyi-sembunyi. Stigma negatif yang melekat pada perbuatan homoseksual menjadikan pelaku homoseksual melakukan aktifitas yang tertutup terutama yang berkaitan dengan perilaku seksual mereka.

Tidak dapat dipungkiri, seiring berjalannya waktu, kehidupan dan kegiatan homoseksual terus mengalami perkembangan dari zaman ke zaman. Pada awalnya LGBT dianggap sebagai tindakan kriminal namun melalui karya Thomas Cannon yang berjudul Ancient and Modern Pederasty Investigated and Exemplify'd yang diterbitkan pada 1749 di Inggris menjadi titik balik perjuangan kaum homoseksual untuk diakui oleh dunia.

Seorang filsuf dibidang sosial bernama Jeremy Bentham pada tahun 1785 secara terang-terangan membela eksistensi kaum homoseksual, hal ini dilakukan melalui sumbangan pemikiran Bentham terhadap aturan hukum homoseksual di Inggris. Berdasarkan pemikiran Bentham tersebut terbentuklah sebuah perubahan terhadap aturan hukum baru yang menyatakan bahwa homoseksual bukanlah sebuah tindakan kriminal.

Inspirasi dari terbitnya aturan hukum baru mengenai LGBT bukan tindakan kriminal menjadikan Perancis sebagai negara pertama yang menerapkan aturan hukum legal bahwa homoseksual bukanlah tindakan kriminal pada tahun 1791. Hal ini kemudian terus diikuti oleh negara-negara lainnya dan menjadi inspirasi bagi terbentuknya organisasi yang bergerak memperjuangakan legalitas kaum homoseksual seperti gerakan free love, the black power, Anti-Vietnam War hingga Gay Liberation Movement.

Puncak pergerakan kaum LGBT untuk mendapatkan pengakuan di mata hukum terjadi di Amerika Serikat pada 28 Juni 1969 tepatnya di Stonewell Inn, Greenwich Village. Kerusuhan ini merupakan interpretasi kaum homoseksual Amerika untuk 
memperjuangkan hak asasi kaum homoseksual internasional, dari gerakan ini kemudian menciptakan komunitas-komunitas yang menjadi wadah kaum homoseksual, terutama untuk mendapatkan jaminan HAM seperti Gay Liberation Front (GLF), The Gay Activits'Allainace (GAA) dan Front Homosexsual d'action Revolutionnaire.

Perjuangan kaum LGBT terus berlanjut hingga pada tahun 1978 terbentuklah International Lesbian and Gay Association (ILGA) di Conventry, Inggris. ILGA didirikan dengan tujuan untuk memperjuangkan hak asasi kaum homoseksual secara internasional dan diterima dikalangan masyarakat luas untuk turut serta dan aktif dalam kegiatan-kegiatan di bidang sosial, ekonomi, politik, dan budaya tanpa memperhatikan persoalan identitas gender mereka.

Kaum LGBT menjadi salah satu kaum yang memiliki pengaruh yang besar pada masa kini, hal ini didasarkan pada prinsip penegakkan HAM yang harus menyamaratakan kedudukan dan status setiap warga negara dalam setiap bidang baik sosial, politik, ekonomi, budaya, dll. Oleh sebab itu, keberadaan kaum LGBT tidak dapat dipisahkan dalam kehidupan bernegara terutama dalam setiap pengambilan keputusan dan kebijakan sebuah negara dewasa ini.

Pertentangan terhadap hak-hak kaum LGBT hingga saat ini masih terus berlangsung, pertentangan ini menimbulkan pro dan kontra di kalangan masyarakat luas terutama dalam aspek HAM. Tidak semua negara di dunia menganut konsep universalisme HAM seperti yang tertuang dalam Deklarasi Universal Hak Asasi Manusia (DUHAM) yang diprakarsai oleh PBB.

\section{Konsep HAM di Amerika dan Indonesia mengenai LGBT}

HAM secara kodrati merupakan hak dasar yang melekat pada setiap individu yang telah ada sejak ia dilahirkan. Kepedulian yang terlampau besar terhadap HAM menjadikan HAM sebagi ujung tombak pelaksanaan penyelenggaraan negara terutama yang berkaitan dengan kesejahteraan, kemakmuran, kemananan, dsb yang berkaitan dengan semua warga negara tanpa memandang status, kasta, dll.

Pertentangan mengenai eksistensi kaum LGBT di kalangan masyarakat dunia menjadi tugas tersendiri bagi penyelenggara HAM untuk merumuskan dan menetapkan kebijakan-kebijakan yang berkaitan dengan nasib kaum LGBT. Hal ini kemudian mendorong terlaksananya seminar internasional yang berlangsung pada 6-9 Nopember 2006, khusus membahas hak-hak kaum LGBT yang berhasil merumuskan prinsip-prinsip penerapan undang-undang HAM yang terkait dengan orientasi seksual dan identitas gender yang dikenal dengan sebutan The Yogyakarta Principle.

The Yogyakarta Principle diprakarsai oleh Non Governmental Organization (NGO) yang bergerak di bidang HAM dan difasilitasi oleh The International Commission of Jurist dan The International Service of Human Rights. Meskipun The Yogyakarta Principle bukan dokumen resmi PBB, namun The Yogyakarta Principle disetujui dan ditandatangani oleh 29 ahli HAM dan ada yang berasal dari perwakilan petinggi PBB. 
Community: Volume 4, Nomor 1, April 2018

ISSN: 2477-5746

Tabel 4.7. Fungsi Utama The Yogyakarta Principle

\begin{tabular}{|c|c|l|}
\hline No. & Fungsi & \multicolumn{1}{|c|}{ Keterangan } \\
\hline 1. & Pertama & $\begin{array}{l}\text { Pemetaan terhadap pengalaman mengenai pelanggaran HAM oleh } \\
\text { orang-orang dari beragam orientasi seksual dan identitas gender }\end{array}$ \\
\hline 2. & Kedua & $\begin{array}{l}\text { Mengaplikasikan pengalaman berdasarkan hukum HAM } \\
\text { internasional yang diartikulasikan secara jelas dan tepat }\end{array}$ \\
\hline 3. & Ketiga & $\begin{array}{l}\text { Merinci kewajiban asli dari negara untuk menerapkan prinsip The } \\
\text { Yogyakarta Principle yang efektif dari setiap kewajiban HAM }\end{array}$ \\
\hline
\end{tabular}

Sumber: Hasil Susunan Penulis

The Yogyakarta Principle terdiri dari 29 prinsip, yaitu:

Tabel 4.8. Tabel The Yogyakarta Principle

\begin{tabular}{|c|c|l|}
\hline No. & Prinsip & \multicolumn{1}{|c|}{ Keterangan } \\
\hline 1. & Prinsip 1 & Hak untuk penikmatan HAM secara universal \\
\hline 2. & Prinsip 2 & Hak atas kesetaraan dan non-diskriminasi \\
\hline 3. & Prinsip 3 & Hak atas pengakuan di mata hukum \\
\hline 4. & Prinsip 4 & Hak untuk hidup \\
\hline 5. & Prinsip 5 & Hak atas keamanan seseorang \\
\hline 6. & Prinsip 6 & Hak atas privasi \\
\hline 7. & Prinsip 7 & $\begin{array}{l}\text { Hak atas kebebasan dari kesewenang-wenangan terhadap } \\
\text { perampasan kebebasan }\end{array}$ \\
\hline 8. & Prinsip 8 & Hak atas pengadilan yang adil \\
\hline 9. & Prinsip 9 & $\begin{array}{l}\text { Hak untuk mendapatkan perlakuan manusiawi selama dalam } \\
\text { tahanan }\end{array}$ \\
\hline 10. & Prinsip 10 & $\begin{array}{l}\text { Hak atas kebebasan dari siksaan dan kekejaman, perlakuan atau } \\
\text { hukuman yang tidak manusiawi atau merendahkan }\end{array}$ \\
\hline 11. & Prinsip 11 & $\begin{array}{l}\text { Hak atas perlindungan dari semua bentuk eksploitasi, } \\
\text { penjualan dan perdagangan manusia }\end{array}$ \\
\hline 12. & Prinsip 12 & Hak untuk bekerja \\
\hline 13. & Prinsip 13 & $\begin{array}{l}\text { Hak atas kemanan sosial dan atas tindakan perlindungan sosial } \\
\text { lainnya }\end{array}$ \\
\hline 14. & Prinsip 14 & Hak untuk mendapatkan standar kehidupan yang layak \\
\hline 15. & Prinsip 15 & Hak atas perumahan yang layak \\
\hline 16. & Prinsip 16 & Hak atas pendidikan \\
\hline 17. & Prinsip 17 & Hak atas pencapaian tertinggi standar pendidikan \\
\hline 18. & Prinsip 18 & Perlindungan atas kekerasan medis \\
\hline 19. & Prinsip 19 & Hak atas kebebasan berpendapat dan berekspresi \\
\hline 20. & Prinsip 20 & Hak atas kebebasan berkumpul dengan damai dan \\
\hline & & \\
\hline Hak
\end{tabular}




\begin{tabular}{|c|l|l|}
\hline & & bersosialisasi \\
\hline 21. & Prinsip 21 & Hak atas kebebasan berpikir \\
\hline 22. & Prinsip 22 & Hak atas kebebasan untuk berpindah \\
\hline 23. & Prinsip 23 & Hak untuk mencari perlindungan \\
\hline 24. & Prinsip 24 & Hak untuk menemukan keluarga \\
\hline 25. & Prinsip 25 & Hak untuk berpartisipasi dalam kehidupan publik \\
\hline 26. & Prinsip 26 & Hak untuk berpartisipasi dalam kehidupan budaya \\
\hline 27. & Prinsip 27 & Hak untuk memajukan HAM \\
\hline 28. & Prinsip 28 & Hak atas pemulihan dan ganti rugi yang efektif \\
\hline 29. & Prinsip 29 & Akuntabilitas \\
\hline
\end{tabular}

Sumber: Hasil Susunan Penulis

Prinsip-prinsip Yogyakarta sangat jelas menegaskan hak-hak yang dimiliki oleh kaum LGBT dengan segala jaminan terhadap hak tersebut, namun pengamalan konsep HAM yang berbeda di beberapa negara menyebabkan implementasi terhadap prinsip Yogyakarta tersebut berbeda. Untuk itu akan diuraikan perbedaan HAM di Amerika dan Indonesia, yaitu:

Tabel 4.9. Perbandingan HAM di Amerika dan Indonesia

\begin{tabular}{|c|l|l|}
\hline No. & \multicolumn{1}{|c|}{ Konsep HAM Barat (Amerika) } & Konsep HAM Asia Afrika (Indonesia) \\
\hline 1. & Meninggalkan konsep negara mutlak & $\begin{array}{l}\text { Tidak boleh bertentangan dengan } \\
\text { ajaran agama atau harus sesuai } \\
\text { dengan kodratnya }\end{array}$ \\
\hline 2. & $\begin{array}{l}\text { Pendirian federasi rakyat yang bebas } \\
\text { dan negara hanya sebatas koordinator } \\
\text { serta pengawas }\end{array}$ & $\begin{array}{l}\text { Masyarakat sebagai keluarga besar } \\
\text { sehingga penghormatan utama } \\
\text { ditujukan kepada kepala keluarga }\end{array}$ \\
\hline 3. & $\begin{array}{l}\text { Filosofi dasar "hak asasi tertanam pada } \\
\text { setiap diri individu" }\end{array}$ & $\begin{array}{l}\text { Individu tunduk kepada adat yang } \\
\text { menyangkut tugas dan kewajiban }\end{array}$ \\
\hline 4. & $\begin{array}{l}\text { Hak asasi lebih dahulu dari pada } \\
\text { tatanan negara }\end{array}$ & \\
\hline
\end{tabular}

Sumber: Hasil Susunan Penulis

Perbedaan penerapan HAM di Amerika dan Indonesia menyebabkan munculnya perbedaan pandangan terhadap eksistensi dan legalitas kaum LGBT di Amerika dan Indonesia. Hal ini tidak terlepas dari prinsip penerapan HAM Amerika yang mengutamakan kebebasan individu sebagai hak mutlak sedangkan Indonesia memandang HAM tidak boleh bertentangan dengan agama maupun adat istiadat.

LGBT di Indonesia pada masa ini bebas berpropaganda menggiring opini publik sehingga memunculkan pro dan kontra di kalangan masyarakat luas. Hal ini terjadi dikarenakan besarnya keterbukaan demokrasi di Indonesia yang memberikan kesempatan bagi setiap elemen untuk menyampaikan pendapatnya seperti civil society, 
law maker, intelektual, aktivis, Lembaga Swadaya Masyarakat (LSM), mahasiswa, maupun tokoh atau lembaga keagamaan hingga publik figur.

Indonesia sebagai negara yang majemuk pada dasarnya menjunjung tinggi keberagaman dan rasa toleransi antar suku, agama, adat, dll. Namun, dominasi Islam sebagai agama mayoritas di Indonesia memberikan pengaruh yang cukup besar dalam setiap kebijakan negara, salah satunya mengenai pengakuan terhadap LGBT.

Pelaku maupun perilaku LGBT di Indonesia dipandang oleh sebagian besar masyrakat merupakan penyimpangan sosial, hal ini dikarenakan pelaku maupun perilaku LGBT tidak sesuai dengan ajaran yang terkandung dalam kepercayaan maupun adat istiadat mayoritas masyarakat Indonesia. Namun, arus globalisasi dan modernisasi yang semakin canggih, terutama dalam penguasaan media massa, telah menciptakan peluang bagi kaum LGBT di Indonesia untuk menampakkan eksistensinya.

Keberhasilan kaum LGBT melakukan propaganda di Indoensia terbukti melalui peningkatan jumlah homoseksual dari tahun ke tahun di Indonesia. Pada 2009, Kementerian Kesehatan (Kemenkes) Republik Indonesia mengeluarkan pernyataan bahwa jumlah homoseksual di Indonesia sekitar 800 ribu jiwa, pada tahun 2012 Kemenkes RI mengeluarkan jumlah terbaru pelaku homoseksual sebanyak 1.095.970 orang.

Data lain yang mendukung semakin besarnya eksistensi LGBT di Indonesia dikeluarkan oleh Perserikatan Bangsa-bangsa (PBB) yang menyebutkan bahwa jumlah LGBT di Indonesia sebanyak 3 juta jiwa pada tahun 2011. Hal ini tidak dapat dinafikkan, mengingat semakin banyaknya organisasi-organisasi LGBT yang tumbuh subur di Indonesia berpayungkan HAM seperti Jaringan Gay, Waria, dan Laki-Laki yang Berhubungan Seks dengan Laki-Laki Lain Indonesia (GWLINA) dan Forum LGBTIQ Indonesia.

Pesatnya perkembangan dan penyebaran LGBT di Indonesia bukan tanpa sebab. Berbagai faktor yang mendukung LGBT di Indonesia di pengaruhi oleh seluruh aspek kehidupan, meskipun Indonesia sendiri 88\% masyarakatnya beragama Islam tetapi tidak dipungkiri ada beberapa individu maupun kelompok yang mengklaim legalitas LGBT di Indonesia atas persamaan HAM.

Faktor yang mendorong perkembangan LGBT di Indonesia, yaitu:

Tabel 4.10. Faktor Pendorong Perkembangan LGBT di Indonesia

\begin{tabular}{|c|l|l|l|}
\hline No. & \multicolumn{1}{|c|}{ Faktor } & \multicolumn{1}{|c|}{ Keterangan } & \multicolumn{1}{c|}{ Contoh } \\
\hline 1. & Globalisasi & Arus globalisasi telah & Penggunaan media sosial \\
& & menghantarkan berbagai & yang saat ini \\
& & macam dampak positif dan & negatif dalam kemajuan sebuah \\
& & trenddigunakan sebagai alat & propaganda terutama \\
& & negara, salah satunya adalah & menyebarkan berita-berita \\
& & teknologi informasi dan & dari belahan dunia lain, \\
\hline
\end{tabular}




\begin{tabular}{|c|c|c|c|}
\hline & & $\begin{array}{l}\text { komunikasi yang berkembang } \\
\text { pesat }\end{array}$ & $\begin{array}{l}\text { seperti banyaknya situs dan } \\
\text { media sosial seperti } \\
\text { facebook, instagram dll } \\
\text { yang bebas } \\
\text { mengkampanyekan } \\
\text { keberadaan LGBT di } \\
\text { Indonesia }\end{array}$ \\
\hline 2. & $\begin{array}{c}\text { Kesempatan } \\
\text { Politik }\end{array}$ & $\begin{array}{l}\text { Rezim berkuasa yang memiliki } \\
\text { kekuasaan dan pengaruh turut } \\
\text { menyuburkan LGBT melalui } \\
\text { berbagai kebijakan, pendapat, } \\
\text { dan keputusan yang } \\
\text { dikeluarkannya, terutama } \\
\text { dalam era demokratisasi } \\
\text { dewasa ini. }\end{array}$ & $\begin{array}{l}\text { Untuk menghalau } \\
\text { pemerintahan dari stigma } \\
\text { otoriter, negara cenderung } \\
\text { memberi kebebasan } \\
\text { bersuara, berpendapat, } \\
\text { berekspresi, dan } \\
\text { berorganisasi yang } \\
\text { cenderung disalahgunakan } \\
\text { (kebablasan), termasuk } \\
\text { salah satunya dengan } \\
\text { cenderung membiarkan } \\
\text { kaum LGBT eksis, seperti } \\
\text { mendirikan salon, membuat } \\
\text { acara khusus kelompok } \\
\text { mereka (pemilihan ratu } \\
\text { kecantiakn waria), dll }\end{array}$ \\
\hline 3. & Ideologi Liberal & $\begin{array}{l}\text { Pandangan kebebasan dan } \\
\text { penghargaan yang cukup } \\
\text { tinggi atas nama HAM menjadi } \\
\text { tolak ukur liberalisme di } \\
\text { Indonesia turut menyuburkan } \\
\text { paham LGBT }\end{array}$ & $\begin{array}{l}\text { Ideologi masyarakat yang } \\
\text { cukup plural di Indonesia } \\
\text { mendorong suburnya } \\
\text { liberalisme dalam } \\
\text { pandangan hidup } \\
\text { masyarakatnya, sehingga } \\
\text { pada sebagian orang } \\
\text { perilaku LGBT bukanlah } \\
\text { sesuau yang melanggar } \\
\text { norma dan etika, seperti } \\
\text { fenomena artis LGBT } \\
\text { semakin mencolok dan } \\
\text { menjadi konsumsi publik } \\
\text { tanpa menimbulkan } \\
\text { pertentangan yang berarti }\end{array}$ \\
\hline
\end{tabular}

Sumber: Hasil Susunan Penulis 
Community: Volume 4, Nomor 1, April 2018

ISSN: 2477-5746

\section{LGBT di Amerika dan Indonesia}

Amerika sebagai negara adidaya yang menjunjung tinggi asas-asas demokrasi memandang HAM sebagai bagian yang tidak terpisahkan dari penegakkan HAM. Oleh sebab itu, keberadaan kaum LGBT di Amerika mendapatkan tempat tersendiri dalam kehidupan sosial masyarakat Amerika.

Legalitas homoseksual di Amerika sudah ada sejak tahun 2003 melalui keputusan Mahkamah Agung Amerika Serikat untuk mengakhiri pelarangan sodomi di Texas dan di 13 negara bagian lainnya keputusan ini diikuti dengan ditandatanganinya deklarasi tersebut oleh PBB. Legalitas kaum homoseksual tersebut kemudian diikuti dengan pengakuan terhadap hak-hak lain seperti pengakuan hubungan sesama jenis, pernikahan sesama jenis yang mulai dilegalkan sejak 2015, adopsi anak oleh pasangan sejenis yang dilegalkan sejak 2015 serta keikutsertaan kaum homoseksual dalam karir militer yang telah diperbolehkan sejak 2010.

Legalitas yang didapat oleh kaum homoseksual di Amerika merupakan bentuk apresiasi negara bagi kebebasan individu yang dijamin haknya dalam konstitusi Amerika. Oleh sebab itu, eksistensi LGBT di Amerika semakin mendapatkan tempat pada setiap bidang kehidupan baik ekonomi, politik hingga militer.

Salah satu lembaga survey terbesar di Amerika yaitu GALLUP mengeluarkan hasil poling terhadap kehidupan LGBT di Amerika. Salah satu polling yang dilakukan ialah mengenai dukungan warga Amerika terhadap pernikahan sesama jenis untuk mendapatkan hak-hak yang sama seperti pernikahan tradisional pada umumnya, survey ini di bagi kedalam dua jawaban yaitu harus disahkan atau tidak harus disahkan, adapun hasilnya seperti yang terdapat pada grafik berikut ini:

Grafik 4.1. Dukungan terhadap Pernikahan sejenis

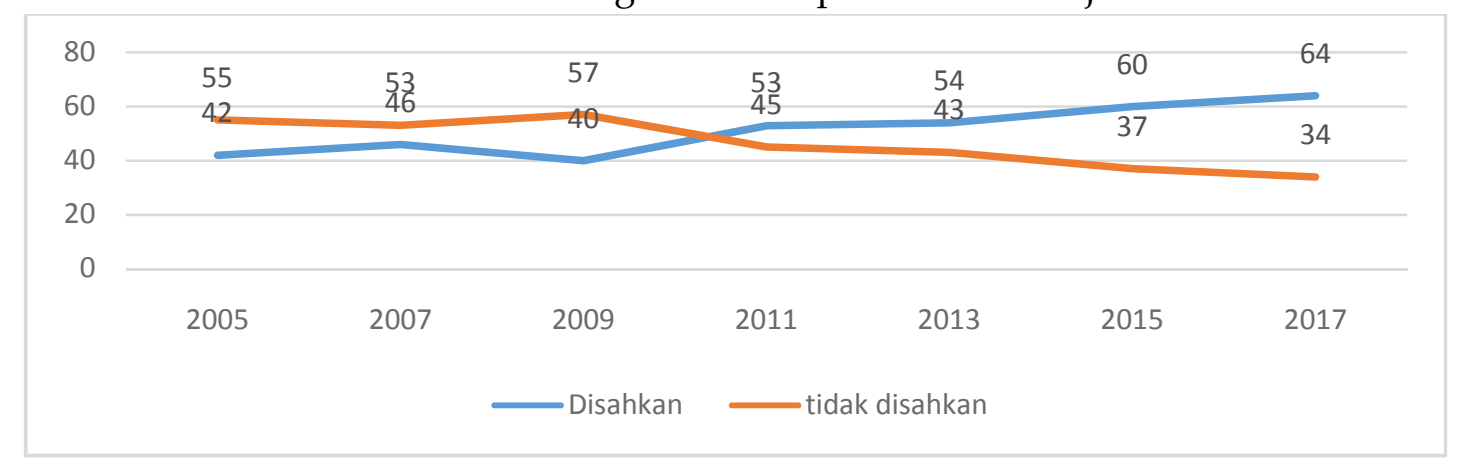

Sumber: Hasil Susunan Penulis

Survey mengenai dukungan terhadap legalitas pernikahan homoseksual di Amerika Serikat setiap tahunnya mengalami kenaikan, walaupun pada 2015 hanya 42\% yang setuju dan 55\% tidak setuju tetapi hingga akhir 2017 dukungan terhadap kaum homoseks terus meningkat, di mana 64\% setuju dan 34\% tidak setuju. Dukungan terhadap legalitas kaum homoseksual tidak terlepas dari dukungan pemerintah Amerika. 
Survey yang dilakukan terhadap eksistensi kaum LGBT untuk mendapatkan hak dan kedudukan yang sama di mata hukum turut didukung oleh partai politik yang ada di Amerika. Dua partai besar Amerika, Demokrat dan Republikan turut serta mendukung legalitas kaum LGBT di Amerika. Dukungan partai politik terhadap LGBT merupakan bentuk kepedulian lembaga partai politik untuk mengakui hak-hak kaum LGBT.

Grafik 4.2 Dukungan Partai Politik untuk LGBT

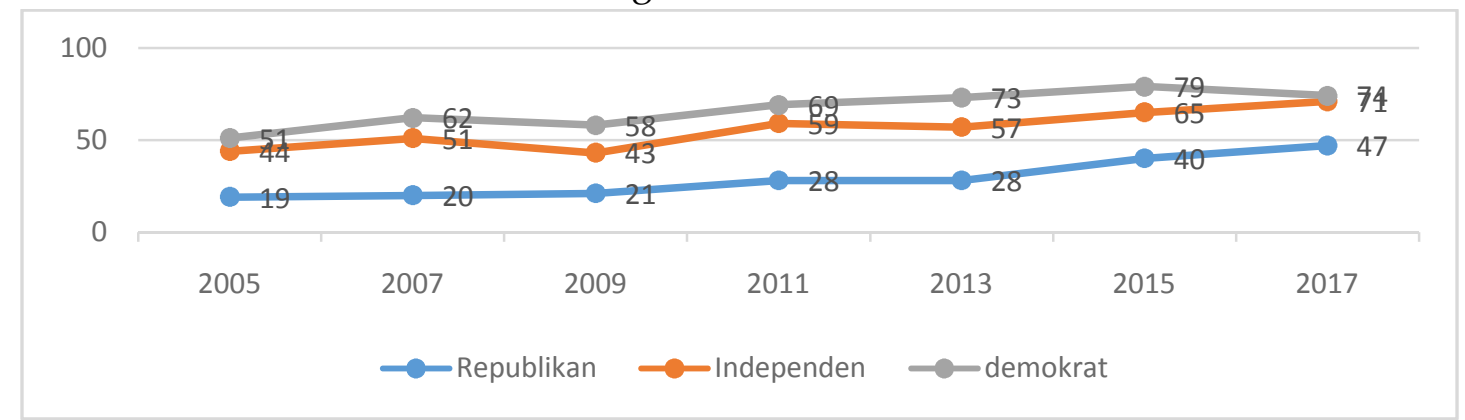

Sumber: Hasil Susunan Penulis

Dukungan partai politik terhadap LGBT di Amerika pertama kali dilakukan oleh partai demokrat, dan pada masa kepemimpinan Obama yang merupakan presiden terpilih dari demokrat yang meluluskan legalitas pernikahan sesama jenis. Partai Republikan pada awalnya kurang memberikan dukungan pada legalitas LGBT di Amerika, namun setiap tahun dukungan Republikan semakin meningkat meskipun tidak sebesar dukungan Demokrat.

LGBT di Amerika pernah mendapatkan penolakan dari sebagian besar penduduk Amerika, hal ini didasarkan kepada ajaran gereja yang menyatakan dengan tegas bahwa perilaku homoseks bertentangan dengan ajaran gereja. Logika penerimaan menjadi dasar bagi pengakuan kaum LGBT oleh ajaran gereja, karena LGBT bukan berarti orang yang memiliki keimanan dangkal atau rendah, hal ini pula yang kemudian mempengaruhi legalitas LGBT di Amerika yaitu dengan munculnya dukungan agama.

Grafik 4.3. Dukungan Keagamaan terhadap LGBT

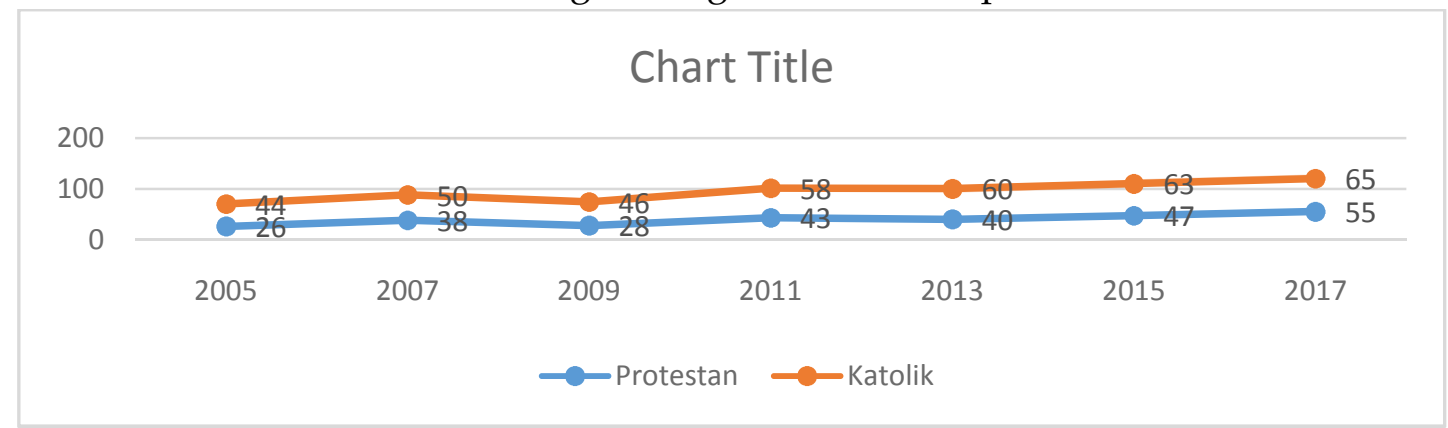

Sumber: Hasil Susunan Penulis 
Kuatnya legalitas LGBT Amerika pada masa kini tidak terlepas dari peran setiap elemen masyarakat yang perduli terhadap kehidupan kaum LGBT. Perjuangan kaum LGBT untuk mendapatkan hak mereka di Amerika tidaklah mudah, berbagai macam propaganda yang mereka mainkan untuk mendapatkan pengakuan masyarakat luas salahsatunya melalui media massa yang begitu signifikan

Pembentukan opini yang menggiring masyarakat, lambat laun mengubah mind set masyarakat Amerika untuk mengakui keberadaan kaum LGBT. Legalitas LGBT di Amerika menjadi momentum terpenting bagi LGBT di dunia, terutama negara-negara yang belum melegalkan LGBT salah satunya adalah Indonesia.

\section{KESIMPULAN}

Keberadaan kaum LGBT di dunia pada saat ini terus berupaya untuk menyamakan hak-hak mereka dengan gender lainnya. Hal ini muncul bukan tanpa sebab, keinginan yang kuat untuk dihargai dan mendapatkan kesempatan yang sama dalam setiap aspek kehidupan bernegara menjadikan kaum LGBT gencar menunjukkan eksistensinya serta berupaya untuk melegalkan eksistensi mereka tersebut.

Persoalan muncul dikarenakan tidak semua negara menganut konsep HAM yang universal, yaitu menyamaratakan setiap hak individu di mata negara, seperti yang terjadi di Amerika. Sejarah panjang perjuangan LGBT di Amerika menunjukkan dari ketidaksetujuan masyarakat Amerika terhadap LGBT menjadi tolak ukur negara lain untuk tetap berjuang dalam menuntut hak mereka, terlebih lagi setelah dilegalkannya pernikahan sesama jenis di Amerika pada tahun 2015 menjadi momentum besar kebangkitan LGBT di negara lain seperti Indonesia.

Indonesia sebagai negara majemuk tidak menafikan konsep HAM sebagai payung dari keanekaragaman sosial yang ada. Namun begitu, dominasi muslim di Indonesia secara langsung turut mempengaruhi setiap kebijakan yang ada meskipun tidak dipungkiri semakin meluasnya ideologi liberal di Indonesia turut mencampuri dan memecah kaum muslim ke dalam beberapa kubu. Tetapi sangat jelas terlihat, meskipun setiap tahun keberadaan LGBT di Indonesia selalu meningkat tetapi legalitas terhadap perilaku mereka belum disahkan, hal ini terjadi karena akumulasi dari norma dan nilai dari agama serta pancasila yang masih sangat dijunjung tinggi.

\section{DAFTAR PUSTAKA}

Crooks, R. \& Baur, K. 2005. Our Sexuality. China: Thomson Wadsworth.

Deklarasi Universal Hak Asasi Manusia (DUHAM). Diterima dan diumumkan oleh Majelis Umum PBB pada tanggal 10 Desember 1948 melalui resolusi 217 A $\{\mathrm{III}\}$. 
Jeffrey S. Nevid. 2005. Psikologi Abnormal. Jilid 2. Jakarta: Erlangga

Masthuriyah Sa'dan. 2016. Agama dan HAM Memandang LGBT. Prosiding Tinjauan Terhadap Lesbian Gay Biseksual dan Transgender (LGBT) Dari Perspektif Hukum Pendidikan dan Psikologi. Hal: 16-25.

Meilanny Budiarti Santoso. LGBT Dalam Perspektif Hak Asasi Manusia. Social Work Jurnal

Volume 6, Nomor 2, Hal: 154-272.

Pius A. Partanto \& M. Dahlan Al Barry. Tt. Kamus Ilmiah Populer. Surabaya: Arkola Prinsip-prinsip Yogyakarta

Sugiyono. 2013. Metode Penelitian Kuantitatif, Kualitatif dan R \& D. Bandung: Alfabeta.

Triana Adhiati. 2007. Gerakan Feminis Lesbian: Studi Kasus Politik Amerika 1990-an. Yogyakarta: Kreasi Wacana.

UNDP. 2014. Laporan LGBT Nasional Indonesia-Hidup Sebagai LGBT di Asia. UNDP Asia Pasifik.

www.gallup.com/home.aspx

Zusy Aryanti. 2016. Faktor Penyebab Terjadinya LGBT pada Anak dan Remaja. Prosiding Tinjauan Terhadap Lesbian Gay Biseksual dan Transgender (LGBT) Dari Perspektif Hukum Pendidikan dan Psikologi. Hal: 42-49. 